\title{
Adequacy of Accounting Information Disclosures of Nigerian Quoted Firms Under IFRS Adoption
}

\author{
Chukwuani Victoria Nnenna \\ ABSTRACT \\ Department of Accountancy, Enugu State University of Technology \\ This study therefore examined the adequacy of accounting information disclosures of Nigerian quoted firms under \\ IFRS adoption in a bid to determine if there is a significant difference in the information content of financial \\ reports as reflected by share prices under IFRS adoption. The stock price informativeness was represented by the \\ market price of shares of firms sampled from the Nigerian Stock Exchange. The paired samples t-test statistics \\ was employed to test the hypothesis of no significant difference in stock prices of quoted Nigerian firms pre and \\ post adoption of IFRS in Nigeria in 2012. Findings from the study show that there is a significant difference stock \\ price informativeness of quoted Nigerian firms after the adoption of IFRS in 2012. Firms are therefore enjoined to \\ improve performance reporting and discard manipulative tendencies. This practice will certainly enhance the stock \\ price informativeness as represented by the market price of shares to ensure appropriate stock pricing.
}

Keywords: Stock Price; Accounting Information Disclosure; IFRS Adoption

DOI: $10.7176 /$ RJFA/10-20-12

Publication date:October $31^{\text {st }}, 2019$

\section{Introduction}

There has been a recent push for the adoption of the International Financial Reporting Standard (IFRS) developed by the IASB (International Accoutning Standards Board). This is due to the ever increasing globalization of the world central and subsidiary economic systems and markets which calls for accounting reports and presentations to be made in a way that accounting information can be interpreted uniformly accross nations. This formed the common ground for the abolition of national accounting report standards among nations and the adoption of IFRS across nations (Armstrong, Barth, Jagolinzer, Riedl, 2010). IFRS adoption received a substantial boost since the European Union (EU) adopted a 1606/2002 regulation in 2002, necessitating all public quoted companies in the EU territory to convert to IFRS starting from 2005 (Iyoha \& Faboyede, 2011). African countries including Ghana, Nigeria, Sierra-Leone, Kenya, South Africa, Zimbabwe, Tunisia, etc. have adopted IFRS or declared intentions to replace their national reporting standards with IFRS. Nigeria particularly launched the adoption of IFRS in September, 2010 (Abata, 2015). The implementation of IFRS in Nigeria was planned to be implemented initially by public listed companies in 2012 so that by 2014 , all stakeholders would have followed consequently. The adoption and implementation of IFRS is a welcome development for underdeveloped and developing countries. Nevertheless the adoption of IFRS has become an issue of major discuss among acountants and scholars. Barth, Landsman and Lang (2008) opined that the adoption of a common body of international reporting standard reflects benefits such as lowered cost of financial information processing and auditing by participants in the capital market, acquaintance with a common international accounting reporting standards instead of various national accounting reporting standards by accountants and financial reports' auditors, uniformity and comparability of financial statements amongst companies and countries - this eases financial analyses, attraction of foreign investors in addition to general capital market liberalization. Ball (2006) opined that developing countries where the quality of local governing institutions is low, the adoption of IFRS will be most beneficial.

Although Kumar (2007) thinks that the adoption of IFRS can attract foreign capital and has the potential to deliver enormous benefits to developing nations, GAB (2012) in Abata (2015) opines differently that countries adopting IFRS could face the problem of forgoing the benefits of any past and potential future innovations in local reporting standards specific to their economies.

Differences in national business practices arising from differences in cultures and institutions cannot be be reflected by single set of accounting standards (Armstrong et al, 2007). Professional accounting and auditing practice is duely regulated by the Companies and Allied Matters Act (CAMA) 1990. This act stipulates the format, scope and content of financial statements, disclosure requirement and auditing. CAMA also expect that companies' financial statements comply with SAS (Statement of Accounting Standards) issued by NASB (Nigerian Accounting Standards Board) from time to time. The auditing of accounting records should also be carried out with generally accepted standards of auditing. The NASB Act No 22 of 2003 is the independent body responsible for issuing and developing SAS for auditors and preparers of financial statements of business concerns and government agencies (Madawaki, 2012). 
Although countries face challenges in the decision to adopt IFRS, its prevalent adoption is supported by the argument that its benefits outweighs its costs (Iyoha \& Faboyede, 2011). Researchers and economists has it that investment flow is influenced by pull factors in host countries; such factors include human capital, natural resources, infrastructure, macroeconomic institutions and available market (Dirk, 2006; Asiedu, 2006; Asiedu and Lien, 2011). This formed the basis for Gordon, Loeb and Zhu (2012)'s argument that the adoption of IFRS cannot inform investment inflow without considering the level of development of adoptee countries. Thus, for the adoption of IFRS to improve investment, the level of development of the adopting countries must be put into consideration (Efobi et al, 2014). Empirical evidence from existing literature indicates positive results associated with the mandatory adoption of IFRS by countries (Patro and Gupta, 2016). Armstrong et al. (2010) documented continuous positive reactions related to IFRS adoption for firms with lower pre-adoption information quality and higher information asymmetry. This suggests that investors perceive that the adoption IFRS will lead to progression in information quality. The research work presented by Dasgupta, Gan, and Gao (2010) indicate that share price involves more firm-related true information after IFRS adoption. Cosequently, stock prices informativeness which is represented by market prices of shares of quoted firms was viewed to reflect adequate accounting information. This study therefore examines the adequacy of accounting information disclosures of Nigerian quoted firms under IFRS adoption. This is in a bid to determine if there is significant difference in the information content of financial reports as reflected by share prices under the adoption of IFRS in 2012.

\section{Review of Related Literature}

\section{Concept of Accounting Information and Financial Reporting}

Accounting is an information system that measures, processes, and communicates financial information about an identifiable economic entity (Kenter and Pressley, 2008). This information by design will guide individuals in making better decisions about business and non-business entities. Accounting provides information to individuals and legal entities about what they have, what they used to have, and the alterations in what they have and what they will have in the future (Alexander, Britton \& Jorissen, 2003). Accounting also makes available changes in what individuals and business entities should have and what they have. Accounting is often seen as carrying out the role of a steward, a steward would have to give account of what has been put under his charge to those who put him in charge of their estate by way of reporting to them regularly (Nyor, 2013). Moreso, Accounting information could be refered to information on the economic activities of business organizations which is identified, measured and communicated to various users to facilitate informed decision making. The identification and recording of financial information or economic information is done by a system of accounting known as double-entry bookkeeping. Measuring accounting information requires making judgment relating to the value of assets and liabilities of a business. It also includes measuring the profit or loss of an organization during an accounting period. An accounting information is considered useful when it is properly communicated to the users of such information. The communication of accounting information is the last stage of financial reporting and it is accomplished through preparing and reporting performance in financial statements, which reflects the financial condition or position of the business organization within an accounting period.

According to IASB $(2006,2008)$, the objective of financial reporting is to provide financial information about the reporting entity to aid potential equity investors, lenders and other creditors in making decisions in their capacity as capital providers. Consequently, Tasios and Bekiaris (2012) citing AICPA (1970) defined the purpose of financial accounting and financial statements as "the provision of quantitative financial information about a business enterprise useful to the statement users". The role of financial reporting however, is broader and "aims to provide evenhanded financial and other information that together with information of other sources facilitates the efficient functioning of capital and other markets and assists the efficient allocation of the scarce resources in the economy"(Tasios and Bekiaris, 2012).

\section{Concept of IFRS}

IFRS (International Financial Reporting Standard) are standards, interpretations and the framework adopted by IASB; IFRSs are products of private sector initiatives towards the harmonization and internationalization of financial reporting in response to the demands of business globalization and regional convergence (Abata, 2015). The IASC (International Accounting Standards Committee) is a body of professional accounting bodies of independent countries, formed in June 1973 by the International Federation Of Accounting, produced the first set of international standards known as the International Accounting Standard (IAS) between 1973 and 2001 (Abata, 2015). The IASB after changing from IASC in 2007 published its standards in a series of statements called the IFRSs (International Financial Reporting Standards). The IASB also absorbed IASC standards, and these standards continued as 'International Accounting Standards (IAS)'. 
IFRS are a single set of high quality, understandable standards for general purpose financial reporting which are principles-based in contrast to the rule based approach. IFRS comprise of four types of documents, viz: IAS (41); IFRSs (18); the Standing Interpretation Committee Statements, SICS (II); and the International Financial Reporting Issues Committee Statements, IFRICS (18), (Azobu, 2010). IFRSs are designed to encourage professional judgment and discourage over reliance on detailed rules (Doubnik \& Perero, 2007). The adoption and implementation of International Accounting Standards were more through persuasion and never mandatory on any country's professional accountancy bodies who are members of these board. These standards have the problem of automatic adoption and by all countries on account of differences in background and tradition of countries, differences in the needs of, and by various economic environment and the perceived challenges to sovereignty of states and enforcing standards (Abata, 2015).

\section{Benefits of Adopting IFRS in Nigeria}

The adoption of IFRS has several benefits as evidenced by previous studies carried out by several scholars some of which include the following: (Leuz \& Verrecchiia, 2000): efficiency of capital allocation, (Young \& Guenther, 2008 in Abata, 2015): international capital mobility, (Ahmed, 2011 in Abata, 2015): capital market development (Adekoya, 2011 in Abata, 2015): increased market liquidity and value (Okere,2009): enhanced comparability (Bhatacharjee \& Hossain, 2010 in Abata, 2015): cross border movement of capital, (Mike,2009 in Abata, 2015): improved transparency of results. According to Abata (2015), the potential benefits that Nigeria stands to gain after IFRS adoption are seen in the light of:

i. Promotion of the compilation of meaningful data on the performance of various reporting entities at both public and private levels in Nigeria thereby encouraging comparability, transparency, efficiency and reliability of financial reporting in Nigeria.

ii. Assurance of useful and meaningful decisions on investment portfolio in Nigeria. Investors can easily compare financial results of corporation and make investment decisions.

iii. Attraction of direct foreign investment. Countries attract investment through greater transparency and a lower cost of capital for potential investors. For example, cross-border listing is greatly facilitated by the use of IFRS.

iv. Assurance of easier access to external capital for local companies.

v. Reduction of the cost of doing business across borders by eliminating the need for supplementary information from Nigerian companies.

vi. Facilitation or easy consolidation of financial information of the same company with offices in different countries. Multi-nationals companies avoid the hassle of restating their accounts in local GAAPs to meet the requirements of national stock exchange and regulators, making the consolidation of accounts of foreign subsidiaries easier and lowering overall cost of financial reporting.

vii. Easier regulation of financial information of entities in Nigeria.

viii. Enhanced knowledge of global financial reporting standards by tertiary institutions in Nigeria.

ix. Additional and better quality financial information for shareholders and supervisory authorities.

x. Government to be able to better access the tax liabilities of multinational companies.

\section{Challenges to IFRS Adoption in Nigeria}

The practical challenges that may be faced in Nigeria as a result of implementing the IFRS need to be identified and addressed in order to benefit fully from the introduction of IFRS. These challenges have been evidenced by previous studies conducted by scholars such as: (Alp \& Ustundag, 2009 in Abata, 2015): potential knowledge shortfall, (Li \& Meeks, 2006 in Abata, 2015): legal system effect, (Shleifer \& Vishny, 2003 in Abata, 2015): tax system effect, (Irvine \& Lucas, 2006 in Abata, 2015): education and training, (Martins, 2011 in Abata, 2015): enforcement and compliance mechanism. Consequently, Abata (2015) discussed the challenges as follows:

Level of Awareness: The transition plan to IFRS and its implications for preparers and users of financial statements, regulators, educators and other stakeholders have to be effectively coordinated and communicated. This should include raising awareness on the potential impact of the conversion, identifying regulatory synergies to be derived and communicating the temporary impact of the transition on business performance and financial position. The implementation of IFRS requires considerable preparation both at the country and entity levels to ensure coherence and provide clarity on the authority that IFRS will have in relation to other existing national laws. 
Accounting Education and Training: Practical implementation of IFRS requires adequate technical capacity among preparers and users of financial statements, auditors and regulatory authorities. Countries that implemented IFRS faced a variety of capacity-related issues, depending on the approach they took. One of the principal challenges Nigeria may encounter in the practical implementation process, shall be the shortage of accountants and auditors who are technically competent in implementing implementation date is not sufficiently long to train a good number of professionals who could competently apply international standards.

Training Resources: Professional accountants are looked upon to ensure successful implementation of IFRS. Along with these accountants, government officials, financial analysts, auditors, tax practitioners, regulators, accounting lecturers, stock-brokers, preparers of financial statements and information officers are all responsible for smooth adoption process. Training materials on IFRS are not readily available at affordable costs in Nigeria to train such a large group which poses a great challenge to IFRS adoption.

Amendment to Existing Laws: In Nigeria, accounting practices are governed by the Companies and Allied Matters Act (CAMA) 1990, and the Statement of Accounting Standards (SAS) issued by the Nigerian Accounting Standards Board (NASB) and other existing laws such as Nigerian Stock Exchange Act 1961, Nigerian Deposit Insurance Act 2006, Banks and Other Financial Institution Act 1991, Investment and Securities Act 2007, Companies Income Tax Act 2004, Federal Inland Revenue Services Act 2007. All these provide some guidelines on preparation of financial statements in Nigeria. IFRS does not recognize the presence of these laws and the accountants have to follow the IFRS fully with no overriding provisions from these laws. Nigerian law makers have to make necessary amendment to ensure a smooth transition to IFRS.

\section{Theoretical Framework: Institutional Theory}

Advanced by Irvine (1999), it asserts that various external and internal forces exert pressure on organizations and in reaction triggers processes that creates homogeneity in the long run. DiMaggio and Powell (1983) categorized them into three and refer to them as isomorphism namely; mimetic, coercive and normative. Under coercive isomorphism, forces acting in the external environment including regulation have great influence on institutional choice (Irvine 1999). Under mimetic isomorphism, organizations have a tendency to copy the behavior of their successful counterparts. Notably, organizations are more inclined to copy peers that are more powerful particularly when uncertainty is pervasive in the environment. An introduction of a new accounting standard creates an uncertainty especially during its implementation phase. This uncertainty is evident among companies and the regulatory bodies. However, organizations that are more powerful will have the determination to effect the changes and in the process set in motion reactionary moves by its peers that are tempted to follow suit. In fact, these powerful organizations are the ones, which introduce changes within the institutional.

Uncertainty drives accounting practice towards standardization. In the context of the current study, jurisdictions across the world adopted IFRS, because of the established procedures of diligent due processes involved in the creation of accounting standards, which were superior to local GAAPs in most countries around the world. This can explain the motivation by Nigeria to bond its financial reporting to IFRS, formulated by IASB considered in this context, as the powerful peer. Normative isomorphism applies when individuals drawn from environments characterized by similar cultural settings and similar economic affiliations opt to work in a familiar environmental dispensation. Such settings gradually create a common understanding of normal behavior. Institutions that employ workers from a common labor market find themselves reeling from the inability to embrace new approaches to problem solving (DiMaggio and Powell, 1983). Thus, these explanations help our understanding of accounting standards within different countries. These include the fact that listed companies in Nigeria constitute a relatively smaller group and constantly face uncertainty when implementing accounting standards. Accordingly, firms and the accounting regulatory body will search for leaders or role models in this field from whom to copy. By a combination of factors IFRS gradually become the benchmark and more developed.

\section{Empirical Review}

Empirical studies have investigated the effects of adopting IAS/IFRS in Europe on investors' perception of accounting quality prior to Regulation 1606/2002, providing evidence in favour of their adoption. By means of disclosure quality scores provided by reputed experts, Daske and Gebhardt (2006) report, for instance, an increase in accounting quality for a sample of Austrian, German, and Swiss firms switching to IAS/IFRS in the period prior to their mandatory adoption in Europe. Similar results are provided by value-relevance studies such as the ones by Bartov, Goldberg \& Kim (2005), which document an increase in the value-relevance of earnings for German firms adopting IAS/IFRS. 
Ashbaugh (2001) works revealed that the decision to report under IAS/IFRS is positively related to corporate size, the number of foreign equity markets on which the firm's shares are traded and the additional issuance of equity shares. Similar findings are reported by Cuijpers and Gassen and Selhorn (2006) and Buijink (2005).

For a sample of European non-financial firms that voluntarily adopted IAS/IFRS, Cuijpers and Buijink (2005) document that foreign listing and geographical dispersion of operations are important drivers.

Gassen and Selhorn (2006) also show that size, international exposure, dispersion of ownership, and IPOs are important determinants of voluntary IAS/IFRS adoption by publicly traded German firms. Findings therefore suggest that companies voluntarily shifting to IAS/IFRS have incentives to improve transparency and the quality of financial reporting. Along the same lines, Covrig, DeFond \& Hung (2007) argued that foreign mutual fund ownership is significantly higher among IAS/IFRS adopters, which suggests a voluntary switch to IAS/IFRS aimed at attracting foreign investors by providing them with both more information and information that is more familiar to them.

Mensah (2013) examined adoption of IFRS in Ghana and quality of financial statement disclosures. The population of the study consisted of listed companies in Ghana between the periods 2006 and 2008. Mensah (2013) adopted descriptive and regression analysis research methods resulting in a disclosure mean of $87.09 \%$ in the post-adoption period compared to $76.8 \%$ in the pre-adoption period and concluded that adoption of IFRS generally reinforce accounting disclosure quality.

Hope, Justin \& Kang (2006) carried out studies to examine empirical evidence on jurisdictions that adopt IFRS. They used sample of 38 countries and employed the CIFAR index to determine transparency of accounting information and reporting approach. The results of the findings showed a negative CIFAR co-efficient which was marginally profound with a t-statistic of -1.95 . In their conclusion, they found negative correlation between adoption of IFRS and investor protection.

Kipchoge (2015) set out to study effects of corporate attributes on international financial reporting standards disclosure levels, evidence from Kenyan listed firms. He employed a descriptive research design and made an observation of a sample of 30 firms using secondary data. The findings revealed positive significant relationship between liquidity and disclosure level with $\beta 3=0.145, \mathrm{p}<0.022$. He concluded there is a considerable degree of relationship between liquidity and IFRS disclosure.

Kingwara (2015) studied the effects of IFRS adoption on reporting quality in Kenya. The sample population consisted of all companies in the list of Nairobi Securities Exchange between the periods 1994-2003. Research methods used include co-efficient for interactive terms of BVPS and EPS of 1.022(t-statistic15.351) and 3.48(tstatistic $=14.355)$ pre-adoption and $(\mathrm{t}$-statistic $=1.161)$ and $.0559(\mathrm{t}$-statistic $=1.71)$ post-adoption respectively. He finds that the value relevance for reported earnings was incrementally higher for listed companies during the postadoption period.

AbdulRazak (2011) carried out a study to examine effects of adopting ifrs on quality of accounting reports of SMEs, in Nairobi County. In a survey study targeting 150 but with a 24 population of 90 firms in Nairobi City council, he employed multiple regression analysis which resulted in a $\beta=0.198$ with significance level of .0001 with IFRS adoption. ANOVA revealed the value of F (36.994) with a significant level of .0001 . Thus, he concluded adoption of IFRS provided positive relation between quality of accounting reports and the various independent variables. This confirms that firms adopting IFRS in Nairobi County and by extension the whole country benefit from transparent financial statements.

Olago (2011) examined effects of IFRS adoption on Small and Medium Enterprises; A case study of Mombasa central business district. He made an observation of 39 firms using secondary and primary data and descriptive data analysis. The findings led him to conclude that IFRS reduces information asymmetry, improves performance and improves decision-making as well as improving comparability of financial statements.

Onafalujo, Eke and Akinlabi (2011) on the impact of international financial reporting standards on insurance management in Nigeria, the paper reports that IFRS improves financial information across borders and enhances economic development.

Olugbenga, Sunday and Soyinka (2016) examined whether the mandatory introduction of International Financial Reporting Standards (IFRS) enhances financial statement comparability. The study specifically investigated the relationship between SAS and IFRS introduction based on key performance indicators of listed firms in Nigeria in 
terms of liquidity, profitability, gearing, reported earnings and market value using the Pearson correlation coefficient. Findings revealed that the introduction of IFRS in Nigeria enhanced credible and qualitative financial statements that would engender economic growth and development. The study therefore recommends that government should empower significantly the financial reporting council of Nigeria (FRCN) to monitor and enforce standards and training to smoothen the introduction of IFRS.

In a related study by Okafor and Killian (2011) on potential effects of the adoption and implementation of IFRS in Nigeria, the study shows that International Financial Reporting Standards have the potential for higher benefits than current NG-GAAP. In a study carried out by, Isenmila and Adeyemo (2013) on a perception based analysis of the mandatory adoption of IFRS in Nigeria, the result shows that there is a statistical significant difference in the perception of the stakeholders regarding the desire for mandatory adoption of IFRS.

A prior study by Lantto and Sahlstrom (2009) on the effect of IFRS adoption on key financial ratios of Finnish listed firms shows that the introduction of IFRS has positively influenced the key accounting ratios. All the key profitability and gearing ratios aresignificantly higher under IFRS adoption. Blanchette, Racicot and Girard (2011) however examined the effect of transition from Canadian GAAP to IFRS on financial ratios in the areas of liquidity, leverage and profitability. They reported significantly higher ratios under IFRS when compared with those derived under pre-Canadian GAAP. In Nigeria, Tanko (2012) reported that firms in Nigeria under IFRS exhibit higher values of profitability measures on earnings per share (EPS).

Abata (2015) examined the impact of International Financial Reporting Standard (IFRS) on financial reporting practices of corporate establishments in Nigeria. Data were collected from 50 employees of KPMG (a leading professional financial services provider) through the use of structured questionnaire and analysed using mean scores, standard deviation and Pearson Chi-square analysis. The findings revealed as follows: that IFRS provides better information for regulators than GAAP; that IFRS directly affects how earnings and other key aspect of the business are accounted and reported for; that changes in business processes and operations, financial position of companies and reduction in cost of finance were the least contributions of IFRS to financial reporting practices of KPMG; the results of Pearson Chisquare analysis showed that financial reports prepared under IFRSs enhanced best practices in a corporate organization; financial statements prepared in line with IFRS provides greater benefits than the former GAAP (SAS); the compliance with IFRS promotes cross border investment and access to; and compliance with IFRS will relatively improve the performance of companies.

Zaiyol, Andrew, Udende (2017) examines whether the adoption of International Financial Reporting Standards (IFRS) improves accountability and quality of accounting information of companies in Nigeria. The study specifically investigates whether the quantitative differences in the financial reports prepared by Nigerian listed companies under SAS and IFRS are statistically significant or not. Secondary data were employed from annual reports of companies in Nigeria using key financial statement content in terms of earning per share, profit for the year and number of disclosureas a means for comparison. B Findings revealed that the quantitative differences in the financial reports prepared under SAS and IFRS are statistically significant. The study therefore concludes that IFRS have impacted on accountability and quality of information from financial statement of Nigerian organization.

\section{Research Gap}

Previous studies have shown inconclusive results and sufficient evidence has not been presented to make the argument for or against the adoption of IFRS. Theoretical argument suggests that adoption of International Financial Reporting Standards (IFRS) will enhance the quality of financial reporting. The argument is based on the notion that using a common accounting standard is expected to improve the quality of financial reporting. On the other hand, several studies have argued that the adoption of IFRS will create room for manipulating accounting numbers, because IFRS is a principle-based set of standards. In other words, IFRS encourages managers to be creative and to use professional judgment, which will decrease the comparability, transparency, relevance and reliability of financial information, and hence have an impact on the quality of reporting. However, such manipulations are penalized in the long-term through pricing of shares. The key question is whether IFRS reports improve the quality of published financial information and particularly for Nigeria. This is the gap filled by this study. This study localized the topic by utilizing data from publicly listed firms in Nigeria to compare periods before and after the adoption of IFRS to determine whether significant differences exist in stock price informativeness by applying the parametric t-test technique. 


\section{Methodology}

In executing this study, the ex-post facto research design was adopted using secondary data of firms quoted on the Nigeria Stock Exchange. On the Nigerian Stock Exchange, quoted firms are classified under twelve (12) industrial classifications and the study purposively sampled a firm each from the twelve (12) industrial classifications. This method ordinarily would give rise to 12 firms but the financial services industry was not considered because firms in the financial services sector do not provide the followings in their audited report (inventory, trade and other receivable, trade and other payables, revenue accruing from sales) and as such the line of business for other sectors is hugely different with that of the financial services sector as well as financial reports. Again, there are no firms recorded under the Utilities sector which comprises establishments engaged in the provision of the following utility services: electric power, steam supply and water supply. For these purposes, the study sample was limited to ten (10) firms with 114 observations.

Empirical evidence from the literature indicate positive consequences associated with the mandatory adoption of IFRS (Patro and Gupta, 2016). Armstrong et al. (2010) document incrementally positive reactions associated with events related to IFRS adoption for firms with lower pre-adoption information quality and higher information asymmetry, which suggests that investors perceive that IFRS will lead to improvements in information quality.Dasgupta, Gan, and Gao (2010) provided evidence that share price involves more firm-related true information after IFRS adoption. The stock price informativeness was represented by the market price of shares of the firms sampled. To this end, the study hypothesized that there is no significant difference in stock prices of quoted Nigerian firms after the adoption of IFRS. The paired sample t-test statistics process is specified thus:

$$
\mathrm{tn}_{1}+\mathrm{n}_{2}-2=\frac{\overline{\mathrm{X}}_{1}-\overline{\mathrm{X}}_{2}}{\mathrm{~S}\left(\mathrm{X}_{1}-\overline{\mathrm{X}}_{2}\right)}
$$

Where:

$\overline{\mathrm{X}}_{\mathrm{SP} 1}=$ Sample mean of stock prices in the pre-IFRS period.

$\overline{\mathrm{X}}_{\mathrm{SP} 2}=$ Sample mean of stock prices in the post-IFRS period.

$\mathrm{S}\left(\mathrm{X}_{1}-\mathrm{X}_{2}\right)=$ the standard deviation of the difference in the pooled variance and thus calculated as:

$$
\begin{aligned}
\mathrm{S}\left(\mathrm{X}_{1}-\mathrm{X}_{2}\right) & =\sqrt{S^{2} P} \quad \ldots \ldots \ldots \ldots \ldots \ldots \ldots \ldots \ldots \ldots \ldots \\
& =\sqrt{S_{X 1}^{2}+S_{X 2}^{2}} \\
& =\frac{\sqrt{\left(n_{1}-1\right) S^{2}+\left(n_{2}-2\right) S^{2}}}{n_{1}+n_{2}-2}
\end{aligned}
$$

Where:

$\mathrm{S}\left(\mathrm{X}_{1}-\mathrm{X}_{2}\right)=$ Population standard deviation.

$\mathrm{S}^{2}{ }_{\mathrm{SP} 1}=$ Sample variance value of stock prices in the pre-IFRS period.

$\mathrm{S}^{2}{ }_{\mathrm{SP} 2}=$ Sample variance value of stock prices in the post-IFRS period.

$\mathrm{S}^{2} \mathrm{P}=$ Pooled variance of the two samples $=\frac{\left(n_{1}-1\right) \mathrm{S}^{2}+\left(n_{2}-2\right) \mathrm{S}^{2}}{n_{1}+n_{2}-2}$

$$
n_{1}+n_{2}-2
$$

$n_{1}=$ Sample size of the pre-IFRS period.

$n_{2}=$ Sample size of the post-IFRS period.

$n_{1}+n_{2}-2=$ Degree of freedom.

\section{Findings}

\section{Test of Hypothesis}

$\mathrm{H}_{0}$ : There is no significant difference in the stock price informativeness of quoted Nigerian firms after the mandatory adoption of IFRS in 2012.

$\mathrm{H}_{1}$ : There is significant difference in the stock price informativeness of quoted Nigerian firms after the mandatory adoption of IFRS in 2012.

Decision rule: Accept $\mathrm{H}_{0}$ if $\mathrm{t}_{\mathrm{c}}<2$ and the $\mathrm{p}$-value $>0.05$, otherwise, reject $\mathrm{H}_{0}$ and accept $\mathrm{H}_{1}$ accordingly. 
Presentation of Test Result.

Paired Samples t-test Statistics for Test of Hypothesis.

Table 1: Paired Samples Statistics

\begin{tabular}{|l|l|l|l|l|l|}
\hline & & Mean & N & Std. Deviation & Std. Error Mean \\
\hline Pair 1 & STOCKPRICEPRE & 27.1398 & 57 & 40.41305 & 5.35284 \\
\cline { 2 - 7 } & STOCKPRICEPOST & 38.3128 & 57 & 60.80693 & 8.05407 \\
\hline
\end{tabular}

Source: Author's SPSS Output Version 17

Table 4.19 shows the Mean of the preIFRS stock price informativeness as 27.1398 with a standard deviation of 40.41305 and postIFRS Mean as 38.3128 with a standard deviation of 60.80693 at an $\mathrm{N}$ of 57 for the pre and post samples.

The paired sample t-test for the earnings quality is presented in table 2.

\begin{tabular}{|c|c|c|c|c|c|c|c|c|c|}
\hline \multicolumn{10}{|c|}{ Table 2: Paired Samples Test } \\
\hline & & \multicolumn{5}{|c|}{ Paired Differences } & \multirow[t]{3}{*}{$\mathrm{t}$} & \multirow[t]{3}{*}{$\mathrm{df}$} & \multirow[t]{3}{*}{ Sig. (2-tailed) } \\
\hline & & \multirow[t]{2}{*}{ Mean } & \multirow[t]{2}{*}{$\begin{array}{l}\text { Std. } \\
\text { Deviatio } \\
\mathrm{n}\end{array}$} & \multirow[t]{2}{*}{$\begin{array}{l}\text { Std. } \\
\text { Error } \\
\text { Mean }\end{array}$} & \multicolumn{2}{|c|}{$\begin{array}{l}95 \% \text { Confidence } \\
\text { Interval of the } \\
\text { Difference }\end{array}$} & & & \\
\hline & & & & & Lower & Upper & & & \\
\hline Pair 1 & $\begin{array}{l}\text { STOCKPRICE } \\
\text { PRE - } \\
\text { STOCKPRICE } \\
\text { POST }\end{array}$ & $-1.11730 \mathrm{E} 1$ & 39.19144 & 5.19103 & -21.57187 & -.77409 & -2.152 & 56 & .036 \\
\hline
\end{tabular}

Source: Author's SPSS Output Version 17

Looking critically at table 2, the paired mean difference of the combined sample for the pre-and post IFRS is 1.11730 with a corresponding $\mathrm{t}$ of $-2.152>2$ and as suchis significant at $.036<0.05$. We therefore reject $\mathrm{H}_{0}$ and conclude that there issignificant difference in stock price informativeness of quoted Nigerian firms after the mandatory adoption of IFRS in 2012 .

The stock price informativeness was represented by the market price of shares of the firms sampled. This finding is in line with empirical evidence from the literature which indicates positive consequences associated with the mandatory adoption of IFRS (Patro and Gupta, 2016). Armstrong et al. (2010) document incrementally positive reactions associated with events related to IFRS adoption for firms with lower pre-adoption information quality and higher information asymmetry, which suggests that investors perceive that IFRS will lead to improvements in information quality.Dasgupta, Gan, and Gao (2010) provided evidence that share price involves more firm-related true information after IFRS adoption. Empirical studies have investigated the effects of adopting IAS/IFRS in Europe on investors' perception of accounting quality prior to Regulation 1606/2002, providing evidence in favour of their adoption. The finding agreed with Mensah (2013) who examined adoption of IFRS in Ghana and quality of financial statement disclosuresconcluded that adoption of IFRS generally reinforce accounting disclosure quality. It agrees with Kingwara (2015) who studied the effects of IFRS adoption on reporting quality in Kenya and found that the value relevance for reported earnings was incrementally higher for listed companies during the post-adoption period.

\section{Conclusion}

Although many countries have faced challenges in their decisions to adopt IFRS, however, its widespread adoption has been promoted by the argument that the benefits outweigh the costs. Empirical evidence from the literature indicates positive consequences associated with the mandatory adoption of IFRS such that incremental positive reactions are associated with events related to IFRS adoption for firms with lower pre-adoption information quality and higher information asymmetry. This suggests that investors perceive that IFRS will lead to improvements in information quality and this is evidenced that share price involves more firm-related true information. To this effect, the stock price informativeness which represented by the market price of shares of quoted firms was viewed 
to reflect adequate accounting information. Thus the adequacy of accounting information disclosures of Nigerian quoted firms under IFRS adoption was examined in a bid to determine if there is significant difference in the information content of financial reports as reflected by share prices under the adoption of IFRS in 2012. Findings from the study show that there isa significant differencestock price informativeness of quoted Nigerian firms after the adoption of IFRS in 2012. Firms are therefore enjoined to improve performance reporting and discard manipulative tendencies. This practice will certainly enhance the stock price informativeness as represented by the market price of shares to ensure appropriate stock pricing.

\section{References}

Abata, M.A. (2015). Impact of IFRS on financial reporting practices in Nigeria (A case of KPMG). Global Journal of Contemporary Research in Accounting, Auditing and Business Ethics, 1(1); 263 - 281

Abdulrazak, J.M. (2013). Effects of adopting IFRS on quality of accounting reports of small and medium enterprises in Nairobi County: Unpublished MBA project, School of Business, University of Nairobi, 824

Alexander, D., Britton A. \& Jorissen, A. (2003). International financial reporting and analysis. London: Thomson Learning.

Armstrong, C.S., Barth, M.E., Jagolinzer, A.D., Riedl, E.J., 2010. Market reaction to the adoption of IFRS in Europe. The Accounting Review 85, 31-61.

Ashbaugh, H. (2001). Non-US firms' accounting standard choices. Journal of Accounting and Public Policy 20 (2), 129-153.

Asiedu, E. (2006). Foreign Direct Investment in Africa: The Role of Natural Resources, Market Size, Government Policy, Institutions and Political Instability. The World Economy, 29(1):63-77.

Asiedu, E., and Lien, D., (2011), Democracy, Foreign Direct Investment and Natural Resources. Journal of International Economics, 84, 99-111.

Azobu, M. (2010). Adoption of IFRS in developing countries. International Journal of Business and Management, $7(3), 155-157$.

Ball, R. (2006). International Financial Reporting Standards (IFRS) pros and cons for investors. Accounting and Business Research: International Accounting policy forum.

Barth, M., Beaver, W. \& Landsman, W. (2001). The relevance of the value relevance literature for financial accounting standard setting: another view. Journal of Accounting and Economics, 31, 77-104.

Barth, M., Landsman, W.R. \& Lang, M. (2008). International Accounting Standards and accounting quality. Journal of Accounting Research 46, 467-498

Bartov, E., Goldberg, S. R., \& Kim, M. (2005). Comparative value relevance among German, US, and international accounting standards: A German stock market perspective. Journal of Accounting, Auditing \& Finance, 20(2), 95-119.

Covrig, V., DeFond, M. \& Hung, M (2007). Home bias, foreign mutual fund holdings, and the voluntary adoption of International Accounting Standards. Journal of Accounting Research, 45, 41-70.

Cuijipers, R. \& Buijink, W. (2005) Voluntary Adoption of Non-Local GAAP in the European Union: A study of Determinants and Consequences. European Accounting Review, 14(3), 487-524.

Daske, H., \& Gebhardt, G. (2006). International Financial Reporting Standards and experts' perceptions of disclosure quality. Abacus, 42 (3-4), 461-498.

Dasgupta, S., Gan, J., \& Gao, N. (2010). Transparency, price informativeness, and stock return synchronicity: Theory and evidence. Journal of Financial and Quantitative Analysis, 45(5), 1189-1220.

Dimaggio, R. \& Powell, W. (1983). The iron cage revisited: Institutional Isomorphism and Collective Rationality in Organizational field.

Doupnik, T.S. and Salter, S.B. (1995). External environment, culture, and accounting practice: A preliminary test of a general model of international accounting development. International Journal of Accounting Education and Research, 30(2): 189-207.

Gassen, J. \& Sellhorn, T. (2006). Applying IFRS in Germany: Determinants and Consequences. Social Science Research Network, 58(4), 1-38.

Gordon, L. A., Loeb, M. P., and Zhu, W., (2012). The impact of IFRS adoption on Foreign Direct Investment. Journal of Account, Public Policy, 31, 374-398.

Hope, O.K., Thomas, W.B. and D. Vyas. (2012). Financial reporting quality of U. S. private and public firms. Rotman School of Management. Working Paper No. 1995124

IASB (2008). Exposure Draft on an improved Conceptual Framework for Financial Reporting: The Objective of Financial Reporting and Qualitative Characteristics of Decision-useful Financial Reporting Information. London. 
Iyoha, F. \& Jimoh, J. (2011). Institutional Infrastructure and the Adoption of International Financial Reporting Standard (IFRS) in Nigeria. School of doctorial studies (European union) Journal, pg18.

Irvine, H. (1999). Money and mission: Who is counting? An institutional Approach to expectations of accounting in religious organization within a changing environment. $\mathrm{PhD}$ Theses, University of Wollongong, Australia.

Kenter, H.A. \& Pressley, M.M. (2008). Uses of accounting information and the Financial statements. Retrieved from http://www.college.hmco.com/accounting/needles/fa/instr/ppt/ch01/sld001.html Accessed 16/08/17

Kingwara, R. A. (2015). Effect of IFRS adoption on reporting quality in Kenya: IOSR Journal of Business Management, 17,82-84

Lantto, A.M. and Sahlström, P. (2009). Impact of international financial reporting standard adoption on key financial ratios. Accounting and Finance, 49 (2): 341-361.

Leuz, C., Nanda, D. and Wysocki, D.P. (2003). Earnings management and investor protection: an international comparison. Journal of Financial Economics, 69: 505-527

Leuz, C., \& Verrecchia, R. E. (2000). The economic consequences of increased disclosure. Journal of Accounting Research, 38(1), 91-124.

Madawaki, A. (2012). Adoption of International Financial Reporting Standards in Developing Countries: The Case of Nigeria. International Journal of Business and Management, 7(3); 152 - 161

Mensah, S. (2004). A review of SME financing schemes in Ghana, Presented at the UNIDO Regional Workshop of Financing Small and Medium Scale Enterprises, Accra, Ghana,3 (2), 369-281

Olago, E. O (2014). The effects of International Financial Reporting Standards Adoption on SMEs Performance: A Case Study Mombasa - Central Business District (CBD): Research/Journal of Finance and Accounting.5 (7), 95-101.

Onafalujo, A.K., Eke, P.O. and Akinlabi, B.H. (2011). Impact of international financial reporting standards on insurance management in Nigeria. Middle Eastern Finance and Economics, Issue 12; 205-220

Patro, A. and Gupta, V. K. (2016). Impact of International Financial Reporting Standards on stock price synchronicity for Asian markets. Contemporary Management Research, 12(1), 61-88.

Patro, A., \& Gupta, V. K. (2014). Impact of International Financial Reporting Standards on Cost of equity Capital for Asian countries. International Journal of Accounting and Financial Reporting, 4(2), 148-170.

Tasios, S. and Bekiaris, M. (2012). Auditor's perceptions of financial reporting quality: the case of Greece. International Journal of Accounting and Financial Reporting, 2(1): 54 - 74

Zaiyol, P.I., Andrew, E.A. and Udende, M.U. (2017). Impact of IFRS adoption on accountability of Nigerian organisations. IOSR Journal of Economics and Finance (IOSR-JEF), 8(1); 60-72 